\title{
Physical-biological coupling in the coastal upwelling system of the Ría de Vigo (NW Spain). I: In situ approach
}

\author{
S. Piedracoba ${ }^{1,2, *}$, M. Nieto-Cid ${ }^{1}$, C. Souto ${ }^{2}$, M. Gilcoto ${ }^{2,3}$, G. Rosón ${ }^{2}$, \\ X. A. Álvarez-Salgado ${ }^{1}$, R. Varela ${ }^{2}$, F. G. Figueiras ${ }^{1}$ \\ ${ }^{1}$ CSIC, Instituto de Investigacións Mariñas, Eduardo Cabello 6, 36208 Vigo, Spain \\ ${ }^{2}$ Facultade de Ciencias do Mar, Universidade de Vigo, Marcosende, 36200 Vigo, Spain \\ ${ }^{3}$ School of Chemistry, Physics \& Earth Sciences, Flinders University, GPO Box 2100, 5001 Adelaide, Australia
}

\begin{abstract}
The fate of the inorganic and organic nitrogen trapped in the coastal upwelling system of Ría de Vigo (NW Spain) was studied at the 2 to 4 d time-scale during July and September 2002. A transient geochemical model was applied to the measured residual currents and concentrations of inorganic nitrogen $\left(\mathrm{N}_{\mathrm{T}}\right)$, and dissolved (DON) and particulate (PON) organic $\mathrm{N}$ to obtain (1) the net balance of inputs minus outputs ( $\mathrm{i}-\mathrm{o})_{i}(2)$ the net accumulation; and (3) the net ecosystem production (NEP) of $\mathrm{N}_{\mathrm{T}}, \mathrm{DON}$ and PON. Previously unaccounted lateral variations in residual currents and $\mathrm{N}$ species concentrations in the ría were considered. The ría was autotrophic during July (average NEP, $107 \mathrm{mg} \mathrm{N} \mathrm{m}^{-2} \mathrm{~d}^{-1}$ ). About $25 \%$ of this material was exported to the shelf and the remaining $75 \%$ was transferred to the sediments or promoted to higher trophic levels. During summer upwelling episodes, 30 to $70 \%$ of the organic $\mathrm{N}$ exported to the shelf came from materials previously accumulated in the ría. By contrast, during summer relaxation, 60 to $70 \%$ of the accumulated organic $\mathrm{N}$ came from in situ conversion of $\mathrm{N}_{\mathrm{T}}$ and the remaining 30 to $40 \%$ was allochthonous. As shown by other authors, NEP was rather low during intense upwelling and increased to high values during its subsequent relaxation. In September, the metabolism changed from heterotrophic to slightly autotrophic (average NEP, $26 \mathrm{mg} \mathrm{N} \mathrm{m}^{-2} \mathrm{~d}^{-1}$ ). The DON and PON imported from the shelf during autumn downwelling experienced a different fate: DON was consumed and PON accumulated in the ría. By contrast, DON and PON were produced in situ at the expense of $\mathrm{N}$ nutrients previously accumulated into the system during autumn relaxation. The roles of vertical convection and turbulent mixing in the fertilization of the photic layer were also assessed. Mixing was the most important fertilization mechanism, ensuring transport of nutrients under upwelling and downwelling conditions.
\end{abstract}

KEY WORDS: Nitrogen fluxes · Geochemical model · Upwelling · Downwelling · Rías Baixas (NW Spain)

\section{INTRODUCTION}

New production (NP; see Table 1 for list of abbreviations) is the fraction of primary production $(P g)$ that is supported by allochthonous nutrient salts (Dugdale \& Goering 1967) and is a key variable for understanding marine ecosystems functioning (e.g. exploitation of marine resources global climate change). Therefore,
NP not only represents the threshold for biomass exploitation (Quiñones \& Platt 1991), but also affects the efficiency of the biological pump as a trap for anthropogenic $\mathrm{CO}_{2}$ (Longhurst 1991).

The most straightforward way to estimate NP is to consider the nutrient balance (input minus output) in a given ecosystem (Smith \& Hollibaugh 1993, Wollast 1993). However, this conceptually simple method 
Table 1. Glossary of relevant terms

\begin{tabular}{|c|c|}
\hline A & Free surface area of the ría \\
\hline$A_{\mathrm{S}}, A_{\mathrm{B}}$ & $\begin{array}{l}\text { Surface and bottom areas of the transverse } \\
\text { section }\end{array}$ \\
\hline $\mathrm{ADCP}$ & Acoustic Doppler current profiler \\
\hline $\operatorname{chl} a$ & Chlorophyll a \\
\hline$C_{\mathrm{S}}, C_{\mathrm{B}}$ & $\begin{array}{l}\text { Average surface and bottom concentra- } \\
\text { tions of } C\end{array}$ \\
\hline DON & Dissolved organic nitrogen \\
\hline DOM & Dissolved organic matter \\
\hline ENACW & Eastern North Atlantic Central Water \\
\hline$F \mathrm{x}$ & $\begin{array}{l}\text { Flux of any species carried by a horizontal } \\
\text { convective flow }\left(Q_{\mathrm{S}}, Q_{\mathrm{B}}\right)\end{array}$ \\
\hline$F_{\mathrm{Z}}$ & $\begin{array}{l}\text { Flux of any species carried by vertical } \\
\text { convective flow }\left(Q_{\mathrm{Z}}\right)\end{array}$ \\
\hline$K_{\mathrm{Z}}$ & Turbulent mixing coefficient \\
\hline LNM & Level of no movement \\
\hline$<N>$ & Brunt-Väisälä frequency \\
\hline $\mathrm{N}_{\mathrm{T}}$ & Dissolved inorganic nitrogen \\
\hline NEP & Net ecosystem production \\
\hline $\mathrm{NEP}_{\mathrm{T}}$ & Net ecosystem production of $\mathrm{N}_{\mathrm{T}}$ \\
\hline $\mathrm{NEP}_{\mathrm{D}}$ & Net ecosystem production of DON \\
\hline $\mathrm{NEP}_{\mathrm{P}}$ & Net ecosystem production of PON \\
\hline $\mathrm{NEP}_{\mathrm{SED}}$ & $\begin{array}{l}\text { Net balance of PON sedimentation, PON } \\
\text { and resuspension and } \mathrm{N}_{\mathrm{T}} \text { diffusion from the } \\
\text { sediment }\end{array}$ \\
\hline$M_{\mathrm{Z}}$ & Vertical diffusive fluxes \\
\hline$o-i$ & Net budget of outputs minus inputs \\
\hline$(0-i)_{T}$ & Net budget of outputs minus inputs of $\mathrm{N}_{\mathrm{T}}$ \\
\hline$(0-i)_{P}$ & Net budget of outputs minus inputs of PON \\
\hline$(0-i)_{D}$ & Net budget of outputs minus inputs of DON \\
\hline PON & Particulate organic nitrogen \\
\hline PAR & Photosynthetic available radiation \\
\hline$Q_{\mathrm{B}}$ & Bottom horizontal flow \\
\hline$Q_{\mathrm{S}}$ & Surface horizontal flow \\
\hline$Q_{\mathrm{Z}}$ & Vertical flow \\
\hline $\mathrm{R}_{\mathrm{i}}$ & Richardson number \\
\hline$\rho$ & Density \\
\hline$U_{0}$ & Tidal velocity amplitude \\
\hline $\mathrm{V}$ & Volume \\
\hline$V_{\mathrm{X}}$ & Horizontal convective velocity \\
\hline$V_{\mathrm{Z}}$ & Vertical convective velocity \\
\hline VMADCP & $\begin{array}{l}\text { Vessel-mounted acoustic Doppler current } \\
\text { profiler }\end{array}$ \\
\hline$\Delta\left(\mathrm{V} \cdot \mathrm{N}_{\mathrm{T}}\right) / \Delta t$ & Accumulation of $\mathrm{N}_{\mathrm{T}}$ \\
\hline$\Delta(\mathrm{V} \cdot \mathrm{DON}) / \Delta t$ & Accumulation of DON \\
\hline$\Delta(\mathrm{V} \cdot \mathrm{PON}) / \Delta t$ & Accumulation of PON \\
\hline
\end{tabular}

involves operational difficulties: velocity and turbulent diffusion profiles, together with nutrient concentrations, have to be determined with a frequency higher than the flushing time of the study system. For this reason, different indirect methods have been developed over the last few decades to evaluate NP.

Gravitational sinking and subsequent mineralization is the main fate of NP in vast areas of the open ocean, where the horizontal circulation is quite slow and most of $\mathrm{Pg}$ is processed within the microbial loop (Legendre \& Rassoulzadegan 1995, Cotner \& Biddanda 2002). Therefore, assuming steady-state conditions, NP should be equal to the sedimentation rate measured at the base of the photic layer (Eppley \& Peterson 1979). In vitro approaches have also been used to estimate $\mathrm{N}$; these include the ${ }^{15} \mathrm{~N}$-labeled nitrate/ammonium+ urea method (Dugdale \& Goering 1967) or the lightdark oxygen incubation method (Strickland \& Parsons 1972), in which it is assumed that the net community production (NCP) estimated in the light bottle is equal to the NP (Quiñones \& Platt 1991). However, the application of the latter method in subtropical gyres has led to controversial results (autotrophic NCP $>0$ or heterotrophic NCP < 0; Williams 1998, Serret et al. 2001, del Giorgio \& Duarte 2002). In any case, the validity of shallow sediment traps (Buesseler 1991, Ducklow et al. 1995), ${ }^{15} \mathrm{~N}$-labeled incubations (Legendre \& Gosselin 1989, Wafar et al. 1995), and light-dark oxygen incubations (Hansell et al. 2004) to estimate NP has been openly challenged.

The evaluation of NP is more difficult in coastal systems, due to the enhanced horizontal advection, and the transference of a significant fraction of $\mathrm{Pg}$ to metazoans (Legendre \& Rassoulzadegan 1995, Cotner \& Biddanda 2002). In the particular case of coastal upwelling systems at temperate latitudes, the short flushing times and the non-steady-state conditions increase the complexity of NP estimation (ÁlvarezSalgado et al. 1996a, Smith \& Hollibaugh 1997). The mass balance approach using sediment traps and/or in vitro incubations may not reflect an accurate NP estimate for these ecosystems (Smith \& Hollibaugh 1997, Álvarez-Salgado et al. 2001).

In this study and its companion paper (Piedracoba et al. 2008 this volume) we estimate the NP in a coastal upwelling system (Ría de Vigo, NW Spain) under contrasting upwelling (July) and downwelling (September) conditions using mass balance, sediment trap, and in vitro incubation approaches. Part I is focused on the estimation of the inputs minus outputs balance of nitrogen species (total nutrients, $\mathrm{N}_{\mathrm{T}}$; dissolved organic nitrogen, DON; particulate organic nitrogen, PON) on a short time-scale $(<4$ d) by combining dynamic and chemical determinations along a transverse section in the central segment of the Ría de Vigo. A mass balance box model was developed to evaluate the relative importance of net accumulation and net ecosystem production (NEP = NP) as a mechanism of organic and inorganic nitrogen trapping in this ecosystem. Previous geochemical balances applied in the Ría de Vigo (Álvarez-Salgado et al. 2000, Gilcoto et al. 2001) estimated the velocity field from salinity and temperature distributions. In the present study, NP was estimated from direct current measurements. In addition, the lateral variability of these currents was considered for the first time. In Part II, the metabolism of the Ría de Vigo is assessed while considering the oxygen production/ 
respiration balance. Sedimentation and microzooplankton grazing rates, estimated for the first time in the Ría de Vigo, are also considered. The NP estimations obtained by the in situ (Part I) and in vitro (Part II) approaches are compared and the possible causes of the observed discrepancies are discussed.

\section{MATERIALS AND METHODS}

Survey area. The Ría de Vigo is a large $\left(2.76 \mathrm{~km}^{3}\right)$ $\mathrm{V}$-shaped indentation in the western coast of the Iberian Peninsula (Fig. 1). It experiences wind-driven upwelling of cold, salty and nutrient-rich Eastern North Atlantic Central Water (ENACW) from AprilMay to September-October (Wooster et al. 1976, Fraga 1981). Upwelling events occur with a 1 to 2 wk frequency (Blanton et al. 1987, Álvarez-Salgado et al. 1993). Downwelling is the dominant process the rest of the year; it is characterized by the advection of warm and nutrient-poor shelf surface water to the ría (Castro et al. 1997). The main tributary is the river Oitabén-
Verdugo, which drains an average annual flow of $15 \mathrm{~m}^{3} \mathrm{~s}^{-1}$ (Nogueira et al. 1997) into San Simón Bay, a semi-enclosed basin of $\sim 20 \mathrm{~km}^{2}$ (Fig. 1).

Sampling strategy. Five stations in the middle segment of the Ría de Vigo ( $41 \pm 2 \mathrm{~m}$ max. depth) were sampled about $1 \mathrm{~h}$ before sunrise on 15, 18, 22 and 26 July and 17, 19, 23 and 26 September 2002. Water samples from Stn 00 (Fig. 1) were taken with a rosette sampler equipped with twelve 101 PVC Niskin bottles with stainless-steel internal springs, while water samples from Stns R01 and R03 located at the northern and southern ends of the segment, were taken with 51 PVC Niskin bottles. At Stn 00, salinity and temperature were recorded with an SBE 9/11 CTD probe attached to the rosette sampler. Conductivity measurements were converted into practical salinity scale values with the equation of UNESCO (1985). Water samples were collected from 5 depths: at the surface or at the depth of $50 \%$ of the photosynthetically available radiation (PAR, $\left.\mu \mathrm{E} \mathrm{m}^{-2} \mathrm{~s}^{-1}\right)$ penetration $(2.5 \pm 0.3 \mathrm{~m})$, at $25 \%$ of PAR penetration $(7 \pm 1 \mathrm{~m})$, at $1 \%$ of PAR penetration $(14.2 \pm 2.2 \mathrm{~m})$, at $26.2 \pm 1.2 \mathrm{~m}$, and at the bottom.

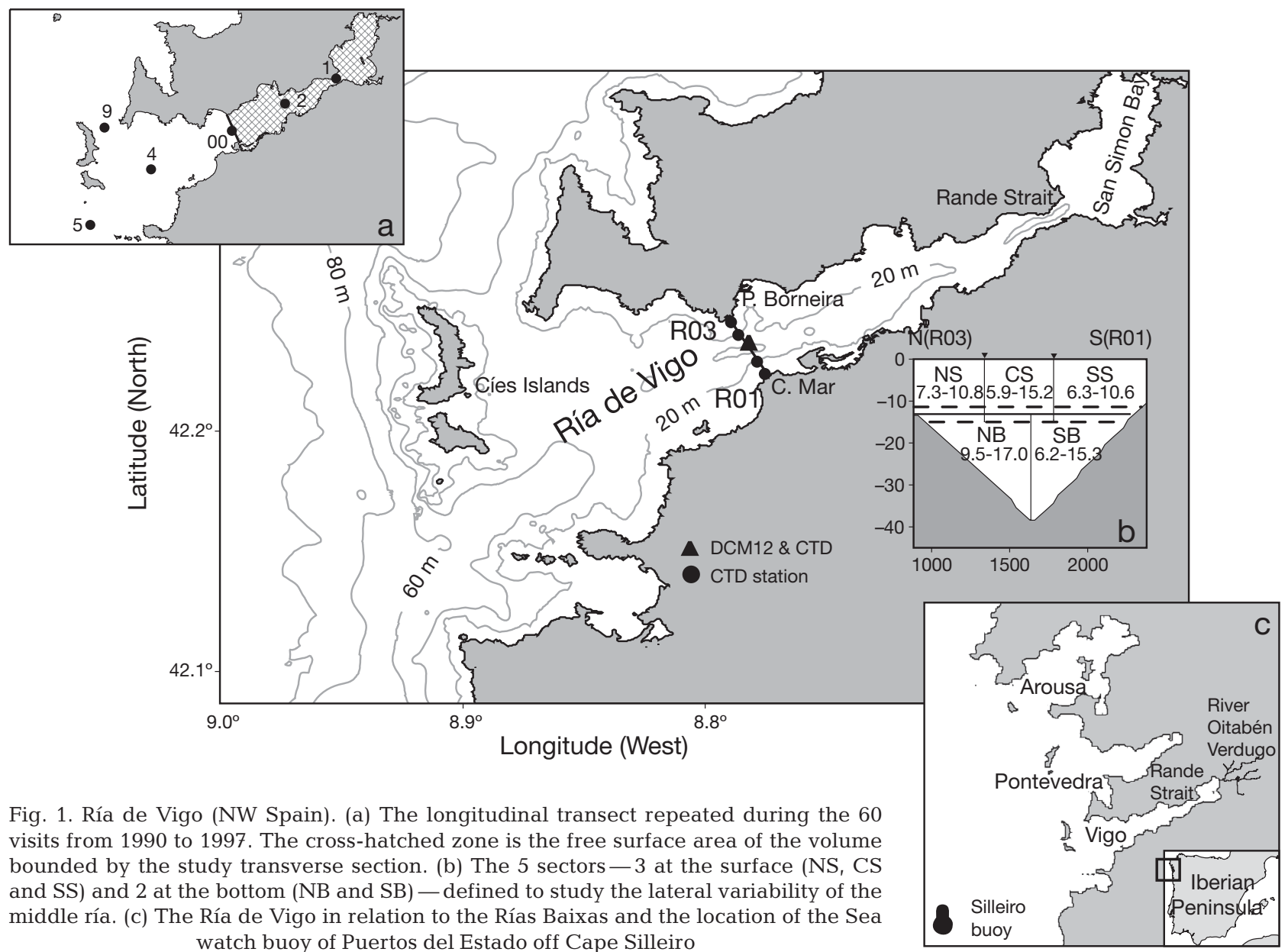


At Stns R01 and R03, salinity and temperature were recorded with a CTD SBE-25 and water samples were collected from 2 depths: surface and bottom.

Wind and current measurements. Coastal wind data were obtained from the Seawatch buoy off Cape Silleiro (www.puertos.es; our Fig. 1), a representative site for winds blowing off the Ría de Vigo (Herrera et al. 2005). Low-pass filtered winds are used to define the prevailing oceanographic scenario in the ría during each period. The heat balance and freshwater flux for each sampling date were taken from Piedracoba et al. (2005).

Current velocity profiles were measured aboard RV 'Mytilus' with an RDI vessel-mounted broadband acoustic Doppler current profiler (VMADCP) of $300 \mathrm{kHz}$ along the transverse section joining Stns R01 and R03 on 18 and 22 July and 19 September 2002. In addition, current profiles were measured with an Aandera DCM12 acoustic Doppler current profiler (ADCP) moored at Stn 00. The mooring was deployed from 10 to 29 July and from 17 to 26 September 2002. The DCM12 lay on the seabed, recording, at $30 \mathrm{~min}$ intervals, the current integrated in 5 vertical cells $11 \mathrm{~m}$ thick. DCM12 and VMADCP data were rotated counterclockwise $30^{\circ}$ to produce a longitudinal and a transversal component relative to the main axis of the ría.

A C++ version of the HAMSOM model (3D, $z$-coordinate Arakawa-C grid), baroclinic, semi-implicit finitedifference numerical prediction model), recently validated in the outer (Souto et al. 2003) and inner (Diz et al. 2004) Ría de Vigo, was used to reproduce the lateral variability of the subtidal current field on 15 and 26 July and 17, 23 and 26 September 2002. The accuracy of the model to reproduce the lateral current field data has been successfully tested by Piedracoba et al. (unpubl.).

Horizontal advection. Five sectors -3 at the surface (NS, CS and SS) and 2 at the bottom (NB and SB) were defined to account for the lateral variability in the middle ría (Fig. 1b). The criterion to divide the surface and bottom sectors was based on the level of no horizontal motion, taking into account the data from the DCM12 and the VMADCP, and the outputs of the HAMSOM model. Horizontal advection velocities were averaged in the 5 sectors.

Vertical advection. The Ría de Vigo was visited for the purpose of measuring mass balances 60 times from 1990 to 1997. Fig. 1a shows the longitudinal transect repeated during the 60 visits. The good relationship between the bottom horizontal flow $\left(Q_{\mathrm{B}}\right)$ and the vertical flow $\left(Q_{\mathrm{Z}}\right)$ obtained from the mass balances (Fig. 1b) permits calculation of the unknown $Q_{Z}\left(i n \mathrm{~m}^{3} \mathrm{~s}^{-1}\right.$ ) from the measured $Q_{\mathrm{B}}$ (in $\mathrm{m}^{3} \mathrm{~s}^{-1}$ ) in this study (n are the pairs of consecutive sampling):

$$
\begin{gathered}
Q_{\mathrm{Z}}=-212( \pm 43)+0.73( \pm 0.03) \cdot Q_{\mathrm{B}} \\
\mathrm{r}=+0.92, \mathrm{p}<0.001, \mathrm{n}=47
\end{gathered}
$$

The vertical convective velocity $\left(V_{\mathrm{z}}\right)$ was calculated considering the surface area of the shaded zone in the inset of Fig. 1a. The vertical displacement of the level of no movement (LNM) between 2 consecutive surveys was also calculated.

Vertical mixing. The turbulent mixing coefficient, $K_{\mathrm{Z}}\left(\mathrm{m}^{2} \mathrm{~d}^{-1}\right)$, was parameterized according to Munk \& Anderson (1948), using the ADCP and CTD data:

$$
\begin{gathered}
K_{\mathrm{Z}}=K_{0} \cdot\left(1+10 \cdot \mathrm{R}_{\mathrm{i}}\right)^{1 / 2} \\
K_{0}=3 \times 10^{-3} \cdot U_{0} \cdot Z \\
\mathrm{R}_{\mathrm{i}}=-\frac{\frac{g}{\rho} \cdot \frac{\partial \rho}{\partial z}}{\left(\frac{\partial u}{\partial z}\right)^{2}}
\end{gathered}
$$

where $K_{0}$ is the eddy coefficient for neutral stability, $U_{0}$ is the amplitude of the tidal velocity from 0 to $Z \mathrm{~m}$ depth, $R_{i}$ is the Richardson number, $\rho$ is the average density, and $g$ is the gravity acceleration. Velocity dimensions were obtained by dividing $K_{\mathrm{Z}}$ by $Z / 2$, the distance between the gravity centers of the upper and lower layer.

Stability. The water column average Brunt-Väisälä frequency, $<N>\left(\right.$ in $\mathrm{min}^{-1}$ ), at $\operatorname{Stn} 00$ (Fig. 1) was calculated as follows: $\left\langle N>=\left\{4 g\left(\rho_{1}-\rho_{u}\right) /\left(\rho_{1}+\rho_{u}\right) Z\right\}^{1 / 2}\right.$, where $\rho_{l}$ and $\rho_{u}$ are the average density of the upper and lower layers.

Chemical variables. Salinity ( $\mathrm{S}_{1}$ accuracy \pm 0.003$)$, $\mathrm{N}$-nutrients $\left(\mathrm{NH}_{4}{ }^{+}, \pm 0.05 \mu \mathrm{M}_{i} \mathrm{NO}_{2}{ }^{-}, \pm 0.02 \mu \mathrm{M}\right.$; and $\left.\mathrm{NO}_{3}{ }^{-}, \pm 0.1 \mu \mathrm{M}\right)$, DON $\left( \pm 0.2 \mu \mathrm{mol} \mathrm{N} \mathrm{l^{-1 }}\right)$, suspended PON $\left( \pm 0.1 \mu \mathrm{mol} \mathrm{N}{ }^{-1}\right)$, and chl a $\left( \pm 0.05 \mathrm{mg} \mathrm{m}^{-3}\right)$ were measured as described elsewhere.

Horizontal/vertical fluxes. Average concentrations $\left(\mu \mathrm{mol} \mathrm{kg}{ }^{-1}\right)$ of all species were calculated from the 3 stations located along the middle segment of the ría by means of an inverse distance interpolation method. The horizontal flux of any nitrogen species $\left(F_{X}\right.$, in $\mu$ mol $\mathrm{m}^{-2} \mathrm{~d}^{-1}$ ) was calculated as follows:

$$
F_{\mathrm{X}}=V_{\mathrm{X}} C_{\mathrm{X}} \rho_{\mathrm{X}}
$$

where $V_{\mathrm{X}}$ is the horizontal velocity, and $C_{\mathrm{X}}$ and $\rho_{\mathrm{X}}$ are the average concentration and density, respectively, at each of 5 sectors defined above.

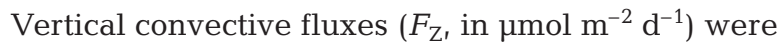
obtained as follows:

$$
F_{\mathrm{Z}}=V_{\mathrm{Z}} C_{\mathrm{Z}} \rho_{\mathrm{Z}}
$$

where $V_{\mathrm{Z}}$ is the vertical convective velocity, and $C_{\mathrm{Z}}$ and $\rho_{Z}$ are the depth-average concentration and density, respectively, in the study section. 
Finally, vertical diffusive fluxes $\left(M_{\mathrm{z}}\right.$ in $\left.\mu \mathrm{mol} \mathrm{m}^{-2} \mathrm{~d}^{-1}\right)$, were obtained as:

$$
M_{\mathrm{Z}}=\frac{K_{\mathrm{Z}}}{\Delta \mathrm{z}}\left(C_{\mathrm{B}}-C_{\mathrm{S}}\right)
$$

where $C_{\mathrm{S}}$ and $C_{\mathrm{B}}$ are the average concentrations of any species in the surface and bottom layer, respectively.

Geochemical budget. The net budget of inputs minus outputs, $\mathrm{i}-\mathrm{O}$, of any species $(C)$ into a given vol-

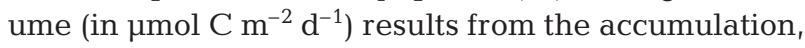
$\Delta(C \cdot \mathrm{V}) / \Delta t$, and net ecosystem production, $\mathrm{NEP}_{\mathrm{C}}$ terms:

$$
\mathrm{i}-\mathrm{o}=\frac{\Delta(C \cdot \mathrm{V})}{\Delta t}-\mathrm{NEP}_{\mathrm{C}}
$$

The accumulation term (in $\mu$ mol $\mathrm{C} \mathrm{m}^{-2} \mathrm{~d}^{-1}$ ) can be separated in 2 terms:

$$
\frac{\Delta(C \cdot \mathrm{V})}{\Delta t}=\frac{\mathrm{V} \Delta C}{\Delta t}+C \cdot \frac{\Delta \mathrm{V}}{\Delta t}
$$

The first term on the right of Eq. (9) indicates the net accumulation due to changes in concentration and the second term due to changes in volume. The average $\mathrm{NEP}_{\mathrm{C}}$ between 2 consecutive surveys can be estimated as:

$$
\mathrm{NEP}_{\mathrm{C}}=\mathrm{o}-\mathrm{i}+\frac{\Delta(\mathrm{V} \cdot \mathrm{C})}{\Delta t}
$$

where the balance of $\mathrm{o}-\mathrm{i}$ (in mol $\mathrm{C} \mathrm{m}^{-2} \mathrm{~d}^{-1}$ ) is calculated as:

$$
\mathrm{o}-\mathrm{i}=\left(F_{\mathrm{S}} \cdot A_{\mathrm{S}}-F_{\mathrm{B}} \cdot A_{\mathrm{S}}\right) / A
$$

$F_{\mathrm{S}}$ and $F_{\mathrm{B}}$ are the average surface and bottom horizontal fluxes (in $\mu \mathrm{mol} \mathrm{m}{ }^{-2} \mathrm{~d}^{-1}$ ); $A_{\mathrm{S}}$ and $A_{\mathrm{B}}$ are the areas of the surface and bottom layer of the transverse section (in $\left.\mathrm{m}^{2}\right)_{;}$and $A$ is the free surface area of the ría bounded by the transverse section $\left(35.6 \times 10^{6} \mathrm{~m}^{2}\right)$.

\section{RESULTS}

\section{Water flows}

Northerly winds prevailed over the shelf in July (Fig. 2a), while southerly winds were dominant in September (Fig. 3a). Since continental runoff was very low in July $\left(<9 \mathrm{~m}^{3} \mathrm{~s}^{-1}\right.$; Fig. 2 b) and September (from 5.7 to $14.5 \mathrm{~m}^{3} \mathrm{~s}^{-1}$; Fig. 3b), 6 periods were defined according to the dominant shelf wind. The first, from 15 to 18 July, was characterized by an intense upwelling episode that reached a maximum on 15 July. A positive residual circulation pattern with a strong surface outflow of $-12 \mathrm{~cm} \mathrm{~s}^{-1}$ was recorded (Fig. 2d). During the second period, from 18 to 22 July, northerly winds abated, producing a reversal of the residual circulation pattern (surface inflow and bottom outflow; Fig. 2d). The third period (22 to 26 July) was dominated by northerly winds that promoted an intense upwelling on 26 July. A positive residual circulation pattern resumed (Fig. 2d), with surface and bottom currents similar to the first period. The fourth period, from 17 to 19 September, was dominated by southeasterly winds that decreased gradually and caused a negative residual current pattern with a maximum surface inflow of $10 \mathrm{~cm} \mathrm{~s}^{-1}$ and bottom outflow of $-10 \mathrm{~cm} \mathrm{~s}^{-1}$ (Fig. 3d). The fifth period, from 19 to 23 September, was characterized by the transition from southerly to northerly winds (Fig. 3a), when the reversal of the residual pattern persisted but current velocities diminished. On 23 September, a 3-layer circulation developed, with outflow through the surface and bottom layers and inflow through the intermediate layer. Finally, the sixth period, from 23 to 26 September, was characterized by moderate northeasterly winds blowing over the shelf with lower intensity than in July (Figs. 2a, 3a). As a result, the 2-layer positive circulation pattern was reestablished.

On 15 July, the salinity and temperature distributions showed the typical response to an upwelling event. Despite the subsequent relaxation of shelf winds, the effect of coastal upwelling still remained in the bottom layer $3 \mathrm{~d}$ later (Fig. 2e,f). The reversal of the circulation in response to the wind calm (Fig. 2a) affected the water column stratification: salinity was more homogeneous and the halocline was difficult to distinguish, while surface temperature increased and the thermocline was found at $20 \mathrm{~m}$ depth. The thermohaline structure found on 17 September corresponded to a typical autumn downwelling, with warm $\left(>17^{\circ} \mathrm{C}\right)$ and relatively salty $(>34.8)$ shelf surface waters in the surface layer (Fig. 3e,f). The persistence of shelf southerly winds produced a deepening of the surface salinity and temperature as a consequence of downwelling. Southerly winds changed to northeasterly on 22 September (Fig. 3a), producing a slight uplift of the isohalines and isotherms, suggesting the entry of oceanic ENACW through the bottom layers on 26 September.

The analysis of the longitudinal component of the residual current shows typical 2-layered positive and negative circulation patterns under upwelling conditions on 15 July (Fig. 4a) and downwelling conditions on 19 September (Fig. 4f), respectively. A variety of intermediate cases were observed on the other sampling dates, showing the complexity of the lateral residual circulation of the ría.

Vertical convective velocities were upwards during the upwelling events of 15 and 26 July (Fig. $4 a, d$ ) and 23 and 26 September (Fig. 4g,h). They were nearly zero during the relaxation of upwelling (Fig. 4b) and reversed to downwards on 22 July (Fig. 4c), and on 17 and 19 September (Fig. 4e,f). In July, mixing velocities 

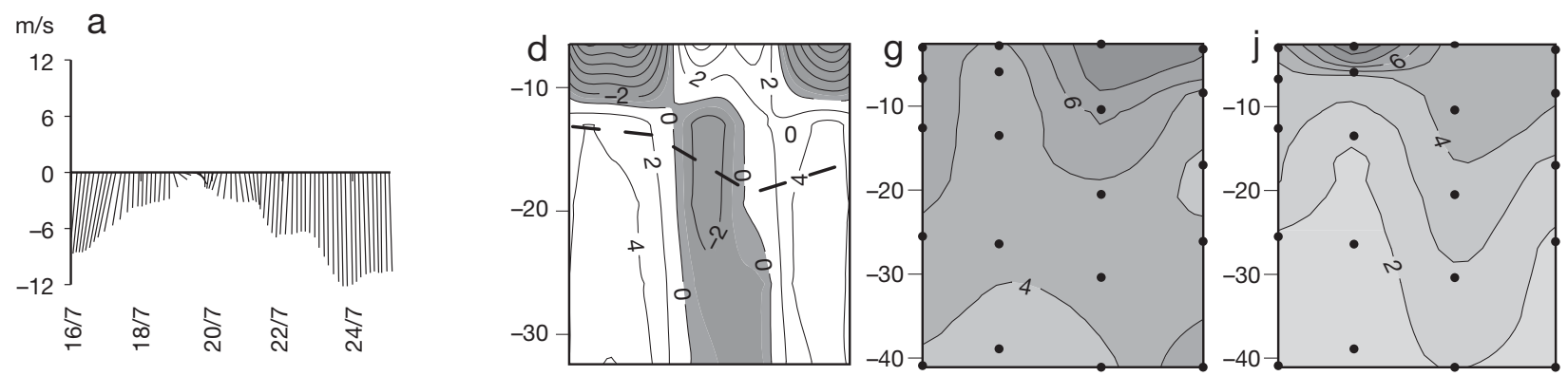

b
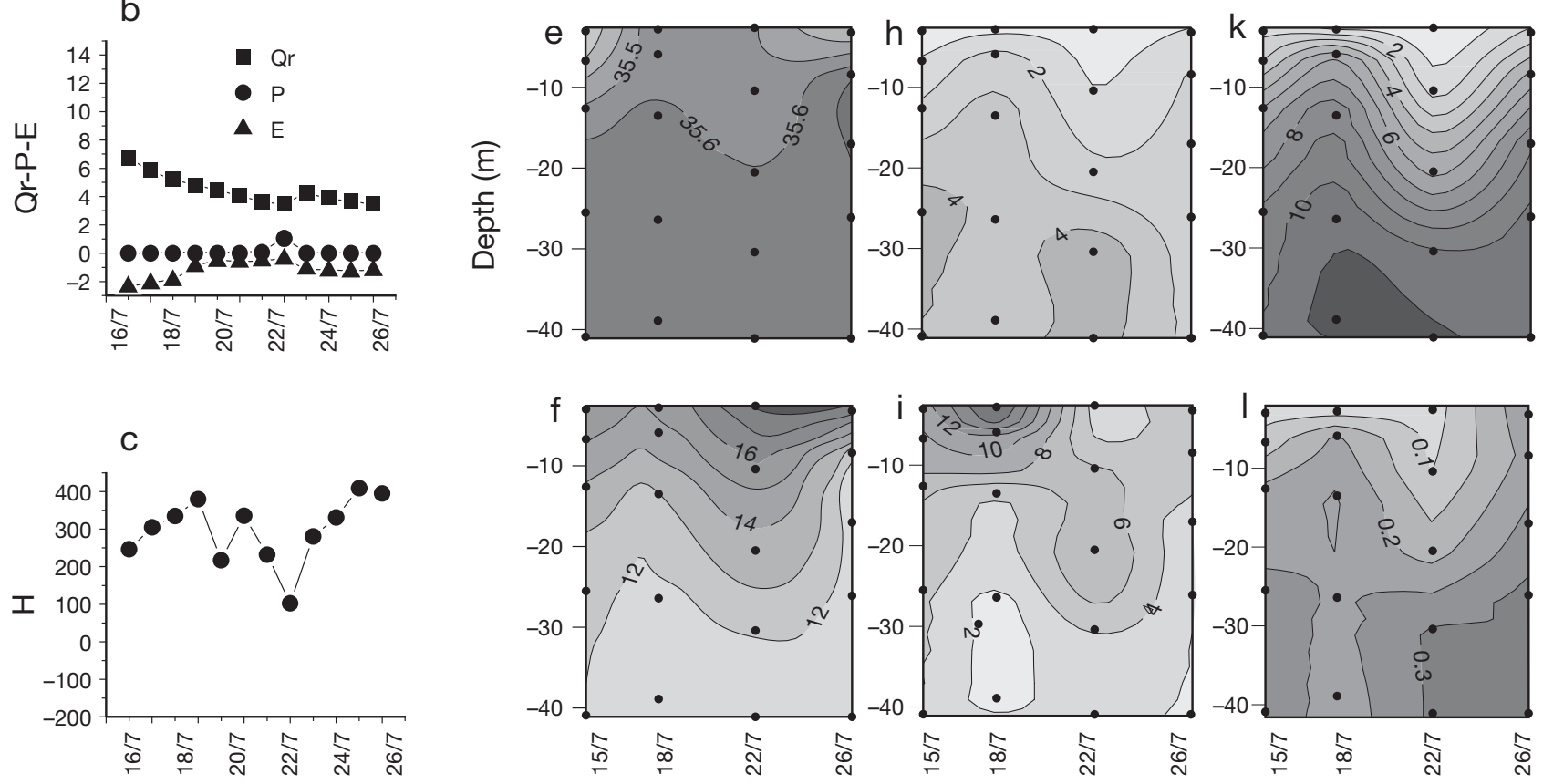

Fig. 2. July 2002. (a) Time course of shelf winds, in $\mathrm{m} \mathrm{s}^{-1}$; (b) continental runoff $(Q r)$, precipitation $(P)$ and evaporation $(E)$, in $\mathrm{m}^{3} \mathrm{~s}^{-1}$; (c) heat balance (H), in cal cm${ }^{-2} \mathrm{~d}^{-1}$; (d) residual currents, in $\mathrm{cm} \mathrm{s}^{-1}$; dashed line represents the pycnocline; (e) salinity; (f) tempera-

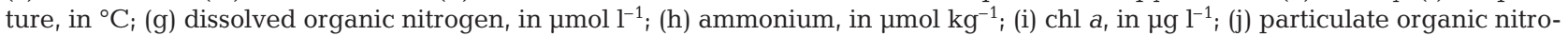

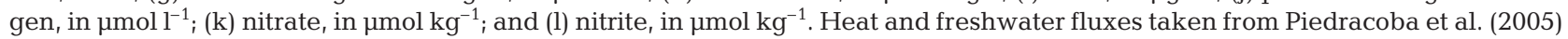

reached a maximum during upwelling events, being twice the vertical convective velocity on 15 July (Fig. 4a). Throughout September, mixing velocity was higher than the convective vertical velocity, except on 17 September, and it reached a maximum on 19 September (Fig. 4f). The stratification that took place during the relaxation after the first upwelling episode caused mixing velocity that was half the vertical convective velocity on 26 July (Fig. 4 d). The vertical displacements of the LNM were negligible compared to the vertical convective and mixing velocities in July and September.

According to our previous hydrographic and dynamic description, the 6 periods were named as follows: (i) spin-down of strong summer upwelling (15 to 18 July), (ii) summer relaxation (18 to 22 July), and (iii) spin-up of weak summer upwelling (22 to 26 July), (iv) autumn downwelling (17 to 19 September), (v) autumn transition (19 to 23 September), and (vi) autumn upwelling (23 to 26 September).

\section{Nitrogen fluxes}

$\mathrm{NO}_{3}^{-}$(Fig. 2k), the most abundant $\mathrm{N}$-nutrient in July $\left(69 \%\right.$ of $\left.\mathrm{N}_{\mathrm{T}}=\mathrm{NO}_{3}{ }^{-}+\mathrm{NO}_{2}{ }^{-}+\mathrm{NH}_{4}{ }^{+}\right)$, was at a maximum at the bottom layer during the spin-down of the strong summer upwelling (15 to 18 July) because of the entry of ENACW. In the surface layer, maximum concentrations of chl a (Fig. 2i) and PON (Fig. 2j) were recorded. During the summer relaxation (18 to 22 July), lower chl $a$ and PON concentrations were recorded at the surface compared with the previous period (15 to 18 July) and a subsurface chl a maximum developed at $20 \mathrm{~m}$ depth (the nutricline). DON (Fig. 2g) accumulation in the surface layer took place at the end of the 

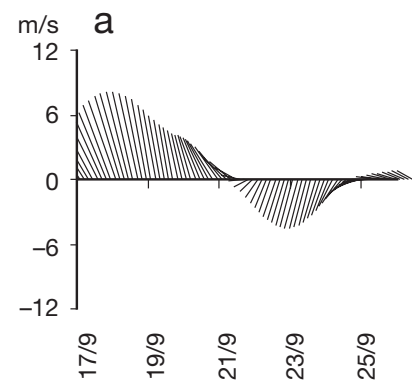

b
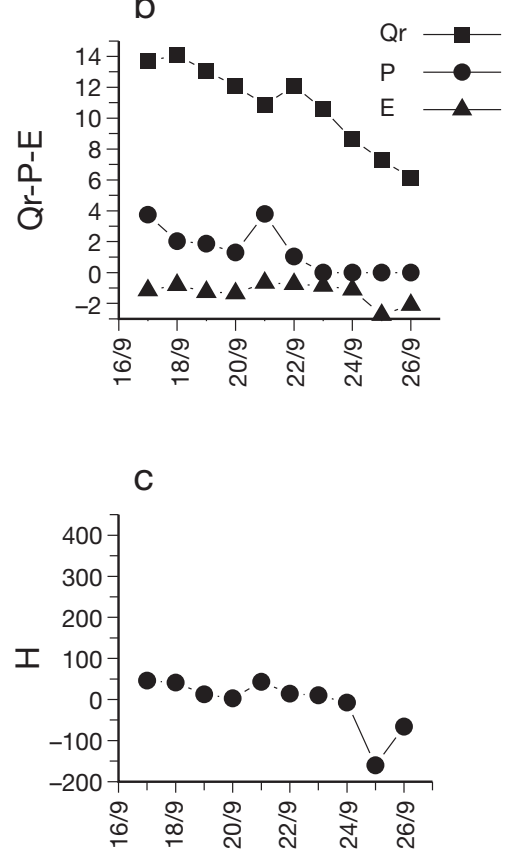
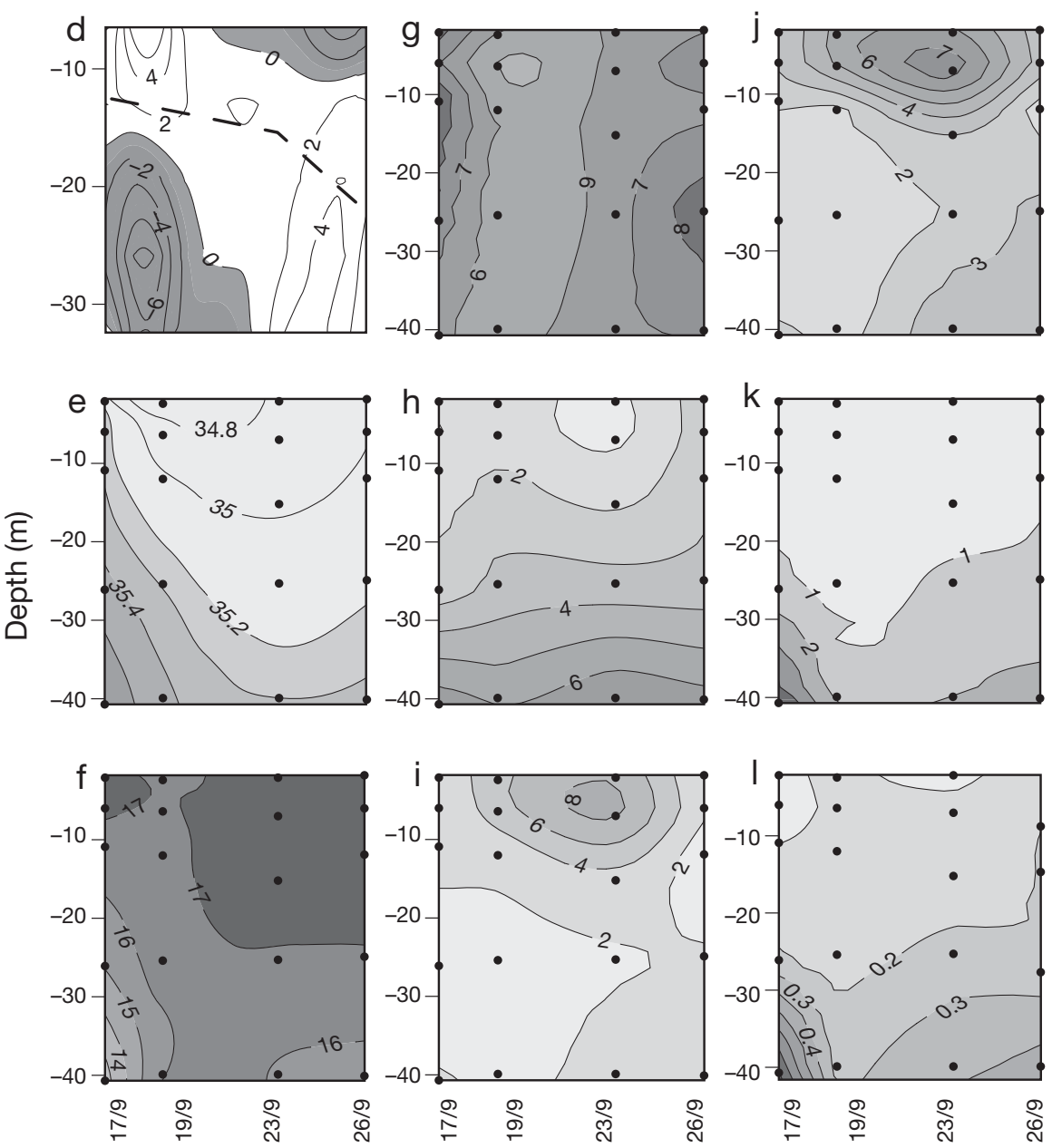

Fig. 3. September 2002. (a) Time evolution of shelf winds, in $\mathrm{m} \mathrm{s}^{-1}$; (b) continental runoff $(Q r)$, precipitation $(P)$ and evaporation $(E)$, in $\mathrm{m}^{3} \mathrm{~s}^{-1}$; (c) heat balance $(\mathrm{H})$, in cal cm${ }^{-2} \mathrm{~d}^{-1}$; (d) residual currents, in $\mathrm{cm} \mathrm{s}^{-1}$ (dashed line: pycnocline); (e) salinity; (f) temperature, in ${ }^{\circ} \mathrm{C}_{i}$ (g) dissolved organic nitrogen, in $\mu \mathrm{mol}{ }^{-1}$; (h) ammonium, in $\mu \mathrm{mol} \mathrm{kg}^{-1}$; (i) chl $a$, in $\mu g \mathrm{l}^{-1}$; (j) particulate organic nitrogen, in $\mu$ mol $\mathrm{l}^{-1}$;

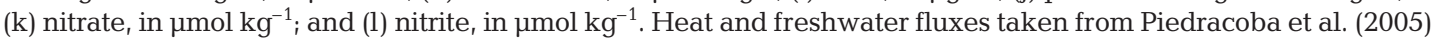

summer relaxation, reaching concentrations $>7 \mu \mathrm{mol}$ $\mathrm{kg}^{-1}$. During the spin-up of weak summer upwelling (22 to 26 July), nutrient-rich water entered through the bottom layers, but this input was weaker compared with the first upwelling period (bottom $\mathrm{NO}_{3}{ }^{-}<11 \mu \mathrm{mol}$ $\mathrm{kg}^{-1}$ ). In contrast with July, $\mathrm{N}$-nutrients levels were reduced by half during September and $\mathrm{NH}_{4}{ }^{+}$(Fig. 3h) was the most abundant form, representing $72 \%$ of $\mathrm{N}_{\mathrm{T}}$. During the autumn downwelling (17 to 19 September), nutrient-poor waters entered from the shelf. Concomitantly, lower PON $\left(\sim 4 \mu \mathrm{mol} \mathrm{kg}{ }^{-1}\right)$ and chl a $\left(\sim 4 \mu \mathrm{kg}^{-1}\right)$ concentrations were measured at the surface layer compared to July (Fig. 3i,j). DON was higher than PON during this period and presented a homogeneous distribution throughout the water column (Fig. 3j). At the beginning of the autumn transition (19 to 23 September), nutrients levels were still very low in the surface layer $\left(\mathrm{NH}_{4}{ }^{+}<1.6 \mu \mathrm{mol} \mathrm{l}^{-1}\right.$ and $\left.\mathrm{NO}_{3}{ }^{-}<0.5 \mu \mathrm{mol} \mathrm{l}^{-1}\right)$, but the wind change caused a progressive entry of ENACW in the bottom layer. The levels of $\mathrm{NO}_{3}{ }^{-}$and $\mathrm{NH}_{4}{ }^{+}$(Fig. 3h,k) increased especially at the beginning of the autumn upwelling (23 to 26 September), although the concentration of $\mathrm{NO}_{3}{ }^{-}$at the bottom was 5 times lower than the levels measured during the weakest summer upwelling ( 22 to 26 July). As a consequence of increasing nutrient levels, high surface chl a

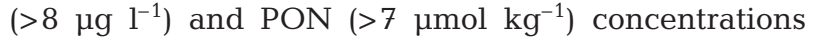
were measured (Fig. 3i,j). As for July, the DON maximum (Fig. 3g) was delayed 3 to $4 \mathrm{~d}$ compared with the chl $a$ and PON maxima.

In July, no significant differences in either nutrient stocks or fluxes were observed between the 2 bottom sectors. By contrast, significant differences $(p<0.05)$ in nutrient fluxes between the 3 surface sectors were observed on most sampling dates (Table 2). DON and PON stocks were very homogeneous through the sur- 


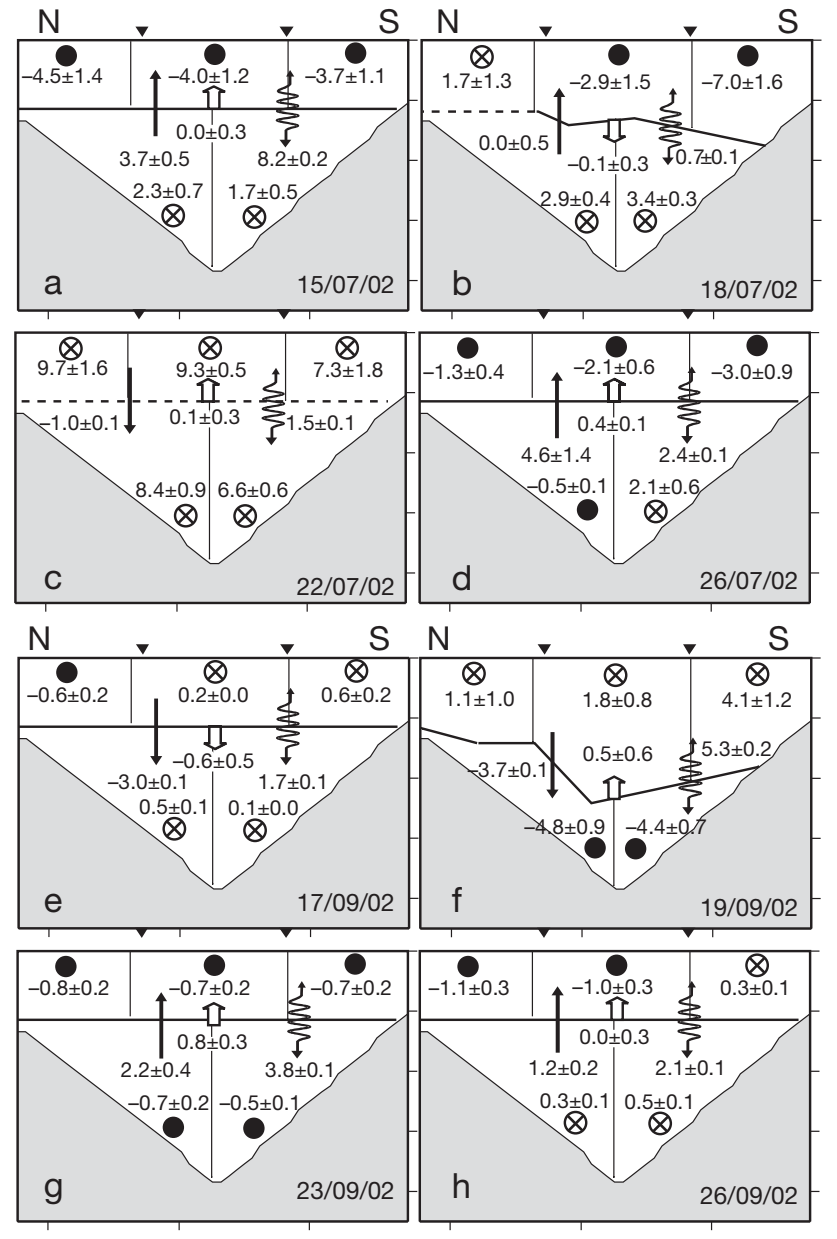

Fig. 4. Time course of horizontal $\left(\mathrm{km} \mathrm{d}^{-1}\right)$ and vertical $\left(\mathrm{m} \mathrm{d}^{-1}\right)$ velocities for each sampling date $(\mathrm{dd} / \mathrm{mm} / \mathrm{yy})$. Solid circle, outflow ( $\mathrm{V}<0$ or westwards) and crossed circle, inflow ( $\mathrm{V}>0$ or eastwards) into the ría; solid arrow, vertical advective velocity (upward, $>0$; downward, <0); zigzag arrow, vertical mixing velocity $\left(K_{\mathrm{Z}} / \Delta z\right)$; white arrow, vertical displacement of the LNM. Sectors are described in Fig. 1b

face and bottom layers, whereas DON and PON fluxes frequently exhibited significant differences $(p<0.05)$ between the 3 surface sectors, especially on 26 July. In September, most of the concentration differences along the transverse section occurred in organic nitrogen. As in July, the fluxes of inorganic and organic species were significantly different between sectors ( $\mathrm{p}<0.05)$, especially on 17 September (Table 3).

\section{Nitrogen budget}

A budget of o-i (in mg $\mathrm{N} \mathrm{m}^{-2} \mathrm{~d}^{-1}$ ) for $\mathrm{N}_{\mathrm{T}}$, PON and DON was estimated considering the fluxes per $\mathrm{m}^{2}$ of free surface area from the middle section to the inner reaches of the ría (Table 4). The lateral variability reported in both the $\mathrm{N}$ species concentrations and the longitudinal component of the residual current was considered in the calculation of $\mathrm{N}$-nutrients, PON and DON fluxes and, therefore, in the corresponding $\mathrm{i}-\mathrm{o}$ balances. In addition, the accumulation terms of all nitrogen species were also calculated $\left(\mathrm{V} \cdot \Delta \mathrm{N}_{\mathrm{T}} / \Delta t\right)$, assuming that the concentrations of $\mathrm{N}_{\mathrm{T}}, \mathrm{PON}$ and DON in the volume of the ría bounded by the middle section do not differ from the concentrations in the middle section. NEP was obtained by summing up o - i and $\mathrm{V} \cdot \Delta \mathrm{N}_{\mathrm{T}} / \Delta t$ (see Eq. 10) for $\mathrm{N}_{\mathrm{T}}\left(\mathrm{NEP}_{\mathrm{T}}\right), \mathrm{DON}\left(\mathrm{NEP}_{\mathrm{D}}\right)$ and PON $\left(N P_{P}\right)$ between 2 consecutive surveys.

During the strong summer upwelling, the volume of the ría bounded by the middle section trapped $-289 \pm$ $17 \mathrm{mg} \mathrm{N} \mathrm{m}^{-2} \mathrm{~d}^{-1}$, i.e. $62 \%$ of the $\mathrm{N}_{\mathrm{T}}$ entry, but only $44 \%$ of $-289 \pm 17 \mathrm{mg} \mathrm{N} \mathrm{m}^{-2} \mathrm{~d}^{-1}$ were transformed into organic matter $\left(\mathrm{NEP}_{\mathrm{T}}=-127 \pm 37 \mathrm{mg} \mathrm{N} \mathrm{m} \mathrm{d}^{-1}\right)$, while $162 \mathrm{mg} \mathrm{N} \mathrm{m}^{-2} \mathrm{~d}^{-1}$ accumulated into the volume. By contrast, the ría was a nutrient source during the subsequent upwelling relaxation $\left(\mathrm{o}-\mathrm{i}=101 \pm 5 \mathrm{mg} \mathrm{N} \mathrm{m}^{-2}\right.$ $\mathrm{d}^{-1}$ ) at the expense of the nutrients accumulated during the previous period. During the following weak upwelling episode, nutrient salts were trapped again, with $57 \%$ utilized for organic matter production and $43 \%$ accumulated into the study volume. During the autumn downwelling the ría acted as a nutrient source $\left(\mathrm{o}-\mathrm{i}=119 \pm 9 \mathrm{mg} \mathrm{N} \mathrm{m} \mathrm{N}^{-2} \mathrm{~d}^{-1}\right)$ at the expense of the nutrients previously accumulated in the system, whereas $\mathrm{NEP}_{\mathrm{T}}$ was balanced $\left(-18 \pm 12 \mathrm{mg} \mathrm{N} \mathrm{m}^{-2} \mathrm{~d}^{-1}\right)$. However, during the subsequent relaxation period, the ría showed a heterotrophic metabolism $\left(\mathrm{NEP}_{\mathrm{T}}>0\right)$, exporting $28 \%$ of the regenerated $\mathrm{N}_{\mathrm{T}}$ to the shelf $(\mathrm{o}-\mathrm{i}$ $=19 \pm 1$ ) and accumulating the remaining $72 \%$ into the ría. Finally, during the weak autumn upwelling, the ría acted as a nutrient trap, $-96 \pm 8 \mathrm{mg} \mathrm{N} \mathrm{m}^{-2} \mathrm{~d}^{-1}$, one third lower than during the weak summer upwelling. Only $27 \%$ of $\mathrm{N}_{\mathrm{T}}$ was consumed to produce organic nitrogen and the remaining $73 \%$ accumulated into the system. As a result, the system changed from heterotrophic to balanced conditions $\left(\mathrm{NEP}_{\mathrm{T}} \sim 0\right)$. During July, the proportion of $\mathrm{NEP}_{\mathrm{T}}$ due to $\mathrm{NO}_{3}{ }^{-}$and $\mathrm{NH}_{4}{ }^{+}$was $67 \%$ and $33 \%$ respectively, whereas during September, the values were $45 \%$ and $55 \%$ respectively.

The fraction of $\mathrm{NEP}_{\mathrm{T}}$ transferred to the sediments $\left(\mathrm{NEP}_{\mathrm{SED}}\right)$ can be inferred indirectly from the following mass balance equation:

$$
\mathrm{NEP}_{\mathrm{T}}+\mathrm{NEP}_{\mathrm{D}}+\mathrm{NEP}_{\mathrm{P}}+\mathrm{NEP}_{\mathrm{SED}}=0 \pm \delta
$$

$\mathrm{NEP}_{\mathrm{SED}}$ is the balance between PON sedimentation and PON resuspension $+\mathrm{N}_{\mathrm{T}}$ diffusion from the sediment (Álvarez-Salgado et al. 1996a). It should be noted that $\mathrm{NEP}_{\mathrm{SED}}$ is calculated with a large uncertainty $( \pm \delta)$, resulting from the individual uncertainties associated with the calculation of $\mathrm{NEP}_{\mathrm{T}}, \mathrm{NEP}_{\mathrm{D}}$ and $\mathrm{NEP}_{\mathrm{P}}$. During the strong and weak upwelling periods, a large frac- 
Table 2. $t$-test of the concentrations and horizontal fluxes of $\mathrm{N}_{\mathrm{T}}, \mathrm{DON}, \mathrm{PON}, \mathrm{NO}_{3}{ }^{-}, \mathrm{NO}_{2}{ }^{-}$and $\mathrm{NH}_{4}{ }^{+}$between the 3 surface (NS, CS and SS) and the 2 bottom (NB and SB) sectors, for each sampling date in July 2002. The p-level was calculated as follows: if $(\overline{\mathrm{x}}-\overline{\mathrm{Y}}) / \sqrt{\sigma_{\mathrm{X}}^{2}+\sigma_{\mathrm{Y}}^{2}}>2.015$, the differences between 2 sectors are significant at $\mathrm{p}<0.05$ (indicated by $\left.{ }^{*}\right)$, whereas if $(\overline{\mathrm{x}}-\overline{\mathrm{Y}}) / \sqrt{\sigma_{\mathrm{X}}^{2}+\sigma_{\mathrm{Y}}^{2}}$ $<2.015$, the difference is nonsignificant (indicated by ns). $\overline{\mathrm{x}}, \sigma_{\mathrm{X}}^{2}$ and $\overline{\mathrm{Y}}, \sigma_{\mathrm{Y}}^{2}$ the mean and variance of the concentrations or fluxes in 2 sectors respectively

\begin{tabular}{|c|c|c|c|c|c|c|c|c|c|c|c|c|c|}
\hline \multirow[t]{2}{*}{ Date } & \multirow[t]{2}{*}{ Sectors } & \multicolumn{6}{|c|}{ Concentrations } & \multicolumn{6}{|c|}{ Fluxes } \\
\hline & & $\mathrm{N}_{\mathrm{T}}$ & DON & PON & $\mathrm{NO}_{3}^{-}$ & $\mathrm{NO}_{2}^{-}$ & $\mathrm{NH}_{4}{ }^{+}$ & $\mathrm{N}_{\mathrm{T}}$ & DON & PON & $\mathrm{NO}_{3}^{-}$ & $\mathrm{NO}_{2}^{-}$ & $\mathrm{NH}_{4}^{+}$ \\
\hline \multirow[t]{4}{*}{15 July } & SS-CS & * & * & ns & ns & * & ns & * & ns & ns & * & ns & * \\
\hline & CS-NS & * & * & $*$ & ns & ns & $*$ & * & $*$ & ns & * & ns & * \\
\hline & SS-NS & * & * & ns & ns & $*$ & * & $*$ & * & ns & ns & ns & * \\
\hline & NB-SB & * & $\mathrm{ns}$ & ns & ns & ns & $\mathrm{ns}$ & ns & $\mathrm{ns}$ & ns & ns & ns & ns \\
\hline \multirow[t]{4}{*}{18 July } & SS-CS & * & ns & $*$ & $*$ & ns & $*$ & $*$ & $*$ & $*$ & $*$ & $*$ & $*$ \\
\hline & CS-NS & $*$ & $\mathrm{~ns}$ & ns & $*$ & $*$ & * & $*$ & * & * & * & * & * \\
\hline & SS-NS & $*$ & $\mathrm{~ns}$ & $*$ & $*$ & $*$ & $*$ & * & $*$ & * & * & * & * \\
\hline & NB-SB & $\mathrm{ns}$ & ns & ns & ns & $\mathrm{ns}$ & $\mathrm{ns}$ & $\mathrm{ns}$ & $\mathrm{ns}$ & ns & $\mathrm{ns}$ & $\mathrm{ns}$ & $\mathrm{ns}$ \\
\hline \multirow[t]{4}{*}{22 July } & SS-CS & $*$ & $\mathrm{~ns}$ & $\mathrm{~ns}$ & $*$ & ns & $*$ & $*$ & $*$ & $*$ & $*$ & $*$ & $*$ \\
\hline & CS-NS & $*$ & $\mathrm{~ns}$ & $\mathrm{~ns}$ & $*$ & ns & $*$ & $*$ & ns & $\mathrm{ns}$ & $*$ & $*$ & $*$ \\
\hline & SS-NS & ns & ns & ns & ns & ns & ns & ns & $*$ & $*$ & ns & ns & ns \\
\hline & NB-SB & $*$ & ns & ns & ns & $\mathrm{ns}$ & $\mathrm{ns}$ & $*$ & $*$ & $*$ & $*$ & ns & $*$ \\
\hline \multirow[t]{4}{*}{26 July } & SS-CS & ns & $\mathrm{ns}$ & $\mathrm{ns}$ & $*$ & $*$ & $*$ & * & * & * & $\mathrm{ns}$ & ns & $*$ \\
\hline & CS-NS & $*$ & ns & ns & ns & * & * & $*$ & $*$ & $*$ & $*$ & $*$ & * \\
\hline & SS-NS & $*$ & ns & ns & ns & $*$ & $*$ & $*$ & * & $*$ & $*$ & $*$ & * \\
\hline & NB-SB & ns & ns & ns & ns & ns & ns & * & $*$ & $*$ & * & $*$ & * \\
\hline
\end{tabular}

Table 3. $t$-test of the concentrations and horizontal fluxes as in Table 2, but for September 2002

\begin{tabular}{|c|c|c|c|c|c|c|c|c|c|c|c|c|c|}
\hline \multirow[t]{2}{*}{ Date } & \multirow[t]{2}{*}{ Sectors } & \multicolumn{6}{|c|}{ Concentrations } & \multicolumn{6}{|c|}{ Fluxes } \\
\hline & & $\mathrm{N}_{\mathrm{T}}$ & DON & PON & $\mathrm{NO}_{3}^{-}$ & $\mathrm{NO}_{2}^{-}$ & $\mathrm{NH}_{4}^{+}$ & $\mathrm{N}_{\mathrm{T}}$ & $\mathrm{DON}$ & PON & $\mathrm{NO}_{3}^{-}$ & $\mathrm{NO}_{2}^{-}$ & $\mathrm{NH}_{4}^{+}$ \\
\hline \multirow{4}{*}{17 Sept } & SS-CS & * & * & * & ns & * & ns & * & * & * & * & * & * \\
\hline & CS-NS & * & $*$ & $*$ & ns & ns & ns & * & * & * & * & * & * \\
\hline & SS-NS & $*$ & ns & ns & ns & ns & ns & * & * & * & * & * & * \\
\hline & NB-SB & ns & $*$ & ns & ns & ns & ns & * & * & $*$ & * & * & * \\
\hline \multirow[t]{4}{*}{19 Sept } & SS-CS & ns & * & $*$ & ns & ns & $\mathrm{ns}$ & $*$ & $*$ & $*$ & ns & $*$ & * \\
\hline & CS-NS & ns & * & ns & ns & ns & ns & ns & ns & ns & $*$ & ns & ns \\
\hline & SS-NS & ns & * & $*$ & ns & $*$ & $\mathrm{~ns}$ & $*$ & $*$ & $*$ & $*$ & $*$ & $*$ \\
\hline & NB-SB & ns & * & $*$ & ns & ns & ns & ns & ns & * & * & ns & ns \\
\hline \multirow[t]{4}{*}{$23 \mathrm{Sept}$} & SS-CS & ns & ns & ns & ns & ns & $\mathrm{ns}$ & $\mathrm{ns}$ & ns & ns & $\mathrm{ns}$ & $\mathrm{ns}$ & ns \\
\hline & CS-NS & ns & ns & ns & ns & $*$ & ns & $\mathrm{ns}$ & $\mathrm{ns}$ & ns & $*$ & ns & $*$ \\
\hline & SS-NS & ns & $\mathrm{ns}$ & $\mathrm{ns}$ & $\mathrm{ns}$ & $\mathrm{ns}$ & $\mathrm{ns}$ & $*$ & $\mathrm{~ns}$ & $\mathrm{~ns}$ & * & ns & * \\
\hline & NB-SB & $*$ & ns & $*$ & ns & ns & ns & * & ns & ns & $*$ & $*$ & * \\
\hline \multirow[t]{4}{*}{$26 \mathrm{Sept}$} & SS-CS & ns & * & * & ns & ns & ns & * & $*$ & $*$ & * & * & * \\
\hline & CS-NS & ns & * & $*$ & ns & ns & $\mathrm{ns}$ & ns & ns & ns & ns & ns & ns \\
\hline & SS-NS & ns & $*$ & ns & ns & ns & ns & $*$ & $*$ & $*$ & $*$ & $*$ & $*$ \\
\hline & NB-SB & $\mathrm{ns}$ & ns & $\mathrm{ns}$ & ns & $\mathrm{ns}$ & $\mathrm{ns}$ & $\mathrm{ns}$ & $\mathrm{ns}$ & ns & $*$ & $*$ & $\mathrm{~ns}$ \\
\hline
\end{tabular}

tion of $\mathrm{NEP}_{\mathrm{T}}$ sank to the bottom $(75 \pm 35 \%$ on 15 to 18 July and $97 \pm 27 \%$ on 22 to 26 July). During the autumn downwelling, the net sedimentation $\left(\mathrm{NEP}_{\mathrm{SED}}\right)$ estimated with Eq. (12) is balanced by the loss of the DON previously accumulated in the system, since $\mathrm{NEP}_{\mathrm{T}}$ was nearly zero. Transformation of DON into sinking particles implies the use of DON as a nutrient source for microheterotrophs (mainly bacterioplank- ton) and its transference to higher trophic levels (zooplankton, hanging mussels) to become sinking particles. The autumn transition was the only period when $\mathrm{NEP}_{\mathrm{SED}}$ was $<0$, which means that resuspension of PON and/or diffusion of $\mathrm{N}_{\mathrm{T}}$ from the sediments was larger than POM deposition over the bottom.

The relative importance of accumulation versus export of DON and PON was also assessed in each period. 
Table 4. Net budget of outputs minus inputs $(\mathrm{o}-\mathrm{i})$, accumulation $\left(\mathrm{V} \cdot \Delta \mathrm{N}_{\mathrm{T}} / \Delta \mathrm{t}\right)$, and net ecosystem production (NEP) and sedimentation (SED) of $\mathrm{N}_{\mathrm{T}}$, DON and PON in July and September 2002 (in $\mathrm{mg} \mathrm{N} \mathrm{m}^{-2} \mathrm{~d}^{-1}$ )

\begin{tabular}{|lcccccccccccc}
\hline Period & Interval & $(\mathrm{o}-\mathrm{i})_{\mathrm{T}}$ & $\mathrm{V} \cdot \Delta \mathrm{N}_{\mathrm{T}} / \Delta \mathrm{t}$ & $\mathrm{NEP}_{\mathrm{T}}$ & $(\mathrm{o}-\mathrm{i})_{\mathrm{D}}$ & $\mathrm{V} \cdot \Delta \mathrm{DON} / \Delta \mathrm{t}$ & $\mathrm{NEP}_{\mathrm{D}}$ & $(\mathrm{o}-\mathrm{i})_{\mathrm{P}} \mathrm{V} \cdot \Delta \mathrm{PON} / \Delta \mathrm{t}$ & $\mathrm{NEP} \mathrm{P}_{\mathrm{P}}$ & $\mathrm{NEP} \mathrm{SED}_{\mathrm{S}}$ \\
\hline $\begin{array}{l}\text { Strong summer } \\
\text { upwelling }\end{array}$ & $15-18 \mathrm{Jul}$ & $-289 \pm 17$ & $162 \pm 21$ & $-127 \pm 37$ & $61 \pm 8$ & $-85 \pm 2$ & $-24 \pm 6$ & $91 \pm 6$ & $-34 \pm 18$ & $57 \pm 24$ & $95 \pm 44$ \\
$\begin{array}{c}\text { Summer } \\
\text { relaxation }\end{array}$ & $18-22 \mathrm{Jul}$ & $101 \pm 5$ & $-136 \pm 1$ & $-35 \pm 5$ & $-13 \pm 4$ & $41 \pm 11$ & $28 \pm 15$ & $-21 \pm 3$ & $35 \pm 22$ & $14 \pm 25$ & $-6 \pm 30$ \\
$\begin{array}{l}\text { Weak summer } \\
\text { upwelling }\end{array}$ & $22-26 \mathrm{Jul}$ & $-280 \pm 14$ & $121 \pm 20$ & $-159 \pm 34$ & $21 \pm 7$ & $-7 \pm 8$ & $15 \pm 14$ & $36 \pm 6$ & $-46 \pm 17$ & $-10 \pm 24$ & $154 \pm 44$ \\
$\begin{array}{c}\text { Autumn } \\
\text { downwelling }\end{array}$ & $17-19 \mathrm{Sep}$ & $119 \pm 9$ & $-137 \pm 4$ & $-18 \pm 12$ & $-9 \pm 13$ & $-155 \pm 5$ & $-163 \pm 8$ & $-94 \pm 8$ & $110 \pm 16$ & $16 \pm 25$ & $165 \pm 29$ \\
$\begin{array}{c}\text { Autumn } \\
\text { transition }\end{array}$ & $19-23 \mathrm{Sep}$ & $19 \pm 1$ & $47 \pm 14$ & $66 \pm 14$ & $1 \pm 1$ & $49 \pm 10$ & $50 \pm 11$ & $-15 \pm 2$ & $32 \pm 22$ & $16 \pm 24$ & $-132 \pm 30$ \\
$\begin{array}{c}\text { Autumn } \\
\text { upwelling }\end{array}$ & $23-26 \mathrm{Sep}$ & $-96 \pm 8$ & $70 \pm 15$ & $-26 \pm 23$ & $-29 \pm 9$ & $68 \pm 9$ & $39 \pm 18$ & $39 \pm 6$ & $-68 \pm 14$ & $-29 \pm 21$ & $15 \pm 36$ \\
\hline
\end{tabular}

The balance of o - i showed that the system acts normally as a source of organic matter under upwelling conditions $(\mathrm{o}-\mathrm{i}>0)$ and as a trap under downwelling or relaxation conditions $(\mathrm{o}-\mathrm{i}<0)$. However, it is necessary to compare this with the accumulation of DON and PON to establish the metabolic status of the system independent of the hydrodynamic conditions (Table 4). During the strong summer upwelling (15 to 18 July) the decrease in DON was due to export $(71 \%)$ and oxidation $(29 \%)$, whereas $63 \%$ of the PON exported to shelf surface waters was produced in situ and the remaining $37 \%$ came from materials previously accumulated in the ría. During the summer relaxation (18 to 22 July) progressive accumulation of DON and PON occurred: $68 \%$ of the DON and $61 \%$ of the PON accumulated in the study volume came from in situ consumption of $\mathrm{N}_{\mathrm{T}}$ and the remaining $32 \%$ and $39 \%$ of DON and PON came from allochthonous materials. During the weak summer upwelling (22 to 26 July) $69 \%$ of the DON exported was produced in situ and the remaining $31 \%$ of DON exported to the shelf came from the materials previously accumulated in the ría. In contrast, $78 \%$ of the PON accumulated previously was exported and the remaining $22 \%$ was oxidized inside the system. During the autumn downwelling (17 to 19 September), there was a net consumption of DON; only $5 \%$ was imported and $95 \%$ came from the material previously accumulated into the system. However, the particulate fraction was accumulated $(15 \%$ of PON was produced in situ and $85 \%$ of PON was imported from the shelf). During the autumn relaxation (19 to 23 September) nearly $100 \%$ of the DON and $50 \%$ of the PON accumulated in the study volume was produced in situ. Finally, during the weak autumn upwelling (23 to 26 September), DON accumulated in the study volume: $42 \%$ imported from the shelf and $58 \%$ produced in situ). In contrast, the PON losses were due to PON consumption (42\%) and export $(58 \%)$.

\section{DISCUSSION}

\section{Vertical convection and diffusion in the fertilization of the photic layer}

The impact of shelf winds on the horizontal circulation of estuaries and coastal inlets has been discussed thoroughly in the literature (Carter et al. 1979, Wong \& Moses-Hall 1998, Janzen \& Wong 2002). In the case of the Galician rías, the issue has also been considered (Rosón et al. 1997, Álvarez-Salgado et al. 2000, Piedracoba et al. 2005). The vertical circulation is also relevant because the fluxes resulting from the combination of convective/diffusive velocities and the gradient of nutrient concentrations are responsible for the fertilization of the photic layer. However, few studies have dealt with the vertical fluxes, mainly because vertical currents are difficult to obtain directly from current meters compared with horizontal currents. In fact, most studies discussing vertical fluxes were carried out in the Galician rías (Álvarez-Salgado et al. 1996a, Rosón et al. 1999, Pérez et al. 2000).

Water flows and nutrient fluxes in the rías were originally calculated with a 2D steady-state box model using salinity as a tracer (Prego \& Fraga 1992). This model did not adequately reproduce the transient upwelling events occurring in the rías. Box models improved when a transient and salt-heat-weighted version was applied to the rías of Arousa (Rosón et al. 1997), Vigo (Álvarez-Salgado et al. 2000) and Pontevedra (Pardo et al. 2001). Finally, a 3D version has been recently developed by Gilcoto et al. (2007), after empirical and numerical confirmation of a 3D residual circulation pattern in the outer part of the Ría de Vigo (Souto et al. 2003). Since the turbulent diffusion velocities obtained by box modeling are as representative for comparable spatial and temporal scales as the turbulent mixing velocities of this study, direct comparisons can be made. 
The mixing velocity $\left(\mathrm{K}_{\mathrm{Z}} / \Delta z\right)$ was nearly twice the vertical convective velocity $\left(V_{\mathrm{Z}}\right)$ during strong summer upwelling (Fig. 4a). The weakness of coastal winds together with thermal stratification $(<N>$ increased by $0.04 \mathrm{~min}^{-1}$ between 18 and 22 July) led to nearly no vertical displacements during the subsequent summer relaxation (Fig. 4b,c). Finally, vertical advection became more relevant with the re-establishment of upwelling conditions, although previous stratification reduced the mixing between layers: $\left(K_{\mathrm{Z}} / \Delta z\right) / V_{\mathrm{Z}} \sim 0.5$ (Fig. 4d) .

Our velocity values are in agreement with the results obtained by Míguez et al. (2001), who applied a 2D transient box model to the middle Ría de Vigo under similar hydrodynamic conditions: an intense upwelling episode after a wind calm in March 1994. However, the $\left(K_{\mathrm{Z}} / \Delta z\right) / V_{\mathrm{Z}}$ ratios obtained by Míguez et al. (2001) ranged from 0.5 to 0.7 ; values of $K_{Z} / \Delta z>V_{Z}$ were not recorded. The 3D transient box model of Gilcoto et al. (2007) also produced an average ratio $\left(K_{\mathrm{Z}} / \Delta z\right) / V_{\mathrm{Z}}$ of $\sim 0.5$ for the upwelling period in the middle Ría de Vigo.

In September, the magnitude of the downward convective velocity during the initial downwelling was comparable to the mixing velocity (Fig. 4e), which reached a maximum on 19 September (Fig. 4f) due to the progressive decrease of stratification $(<N>$ decreased by $-0.05 \mathrm{~min}^{-1}$ between 17 and 19 September). ( $\left.K_{\mathrm{Z}} / \Delta z\right) / V_{\mathrm{Z}}$ was comparable with the ratio calculated by Míguez et al. (2001) under downwelling conditions in October 1994: $V_{\mathrm{Z}}$ ranged from -3.7 to $-4.7 \mathrm{~m} \mathrm{~d}^{-1}$ and $\left(K_{\mathrm{Z}} / \Delta \mathrm{z}\right)$ increased from 0.3 to $3.6 \mathrm{~m} \mathrm{~d}^{-1}$ in agreement with the progressive decrease of water column stability. Gilcoto et al. (2007) obtained a ratio $>0.7$ during a downwelling period in December.

Subsequently, stratification $(<N>$ increased by $0.01 \mathrm{~min}^{-1}$ from 19 to 23 September) reduced the mixing velocity during the autumn transition (Fig. 4g), and at the beginning of the autumn upwelling (Fig. 4h), although the decrease was not as intense as in July. In fact, excluding 17 September, mixing velocities were always larger than vertical convective velocities.

Average $\left(K_{\mathrm{Z}} / \Delta z\right) / V_{\mathrm{Z}}$ ratios obtained by Álvarez-Salgado et al. (2000) with a 2D transient box model for the whole Ría de Vigo were in agreement with the ratios obtained in the present study. The multiparameter inverse method applied to the Ría de Vigo during September 1990 and 1991 by Álvarez-Salgado \& Gilcoto (2004) also reproduced similar average $\left(K_{\mathrm{Z}} / \Delta z\right)$ and $V_{\mathrm{Z}}$ in both periods: $<1.5 \mathrm{~m} \mathrm{~d}^{-1}$, i.e. low compared with the vertical velocities calculated in the present study.

Our vertical velocities were also comparable with the values obtained in the middle Ría de Arousa for the upwelling and downwelling season of 1989 (Rosón et al. 1999). $\left(K_{\mathrm{Z}} / \Delta z\right) / V_{\mathrm{Z}}$ was 0.8 for the up- welling season, indicating that advection was the prevalent mechanism, whereas in the Ría de Vigo, mixing was sometimes up to twice the advection. During an autumn downwelling period in October 1989, the absolute value of $\left(K_{\mathrm{Z}} / \Delta z\right) / V_{\mathrm{Z}}$ was $\sim 0.3$ in the middle Ría de Arousa. By contrast, $\left(K_{Z} / \Delta z\right)$ was nearly equal to $V_{Z}$ in the Ría de Vigo under the same conditions. These observations suggest that turbulent mixing is more important in Vigo than in Arousa. This is probably due to the longer flushing time $(60 \%)$ of the Ría de Arousa, as derived from the relationship between the volume (Arousa, $4.34 \mathrm{~km}^{3}$; Vigo, $3.12 \mathrm{~km}^{3}$ ) and the width of the open boundary (Arousa, $6.7 \mathrm{~km}$; Vigo, $7.7 \mathrm{~km})$ in both rías: $(4.34 \times$ $7.7) /(3.12 \times 6.7)$. A longer flushing time together with a $30 \%$ larger free surface area (230 vs. $176 \mathrm{~km}^{2}$ ) favors stratification in the Ría de Arousa compared with the Ría de Vigo.

Vertical nutrient fluxes depend not only on the magnitude of $\left(K_{\mathrm{Z}} / \Delta z\right)$ and $V_{\mathrm{Z}}$, but also on the vertical profiles of nutrient concentrations. In July, mixing controlled the vertical transport of $\mathrm{N}_{\mathrm{T}}$ it was 6 times larger than that by advection during the strong summer upwelling (15 to 18 July). During the upwelling relaxation (18 to 22 July), vertical mixing fertilized the photic layer in spite of the downward advection of $\mathrm{N}_{\mathrm{T}}$. By contrast, the transport of inorganic nitrogen by mixing was one third of that by advection over the upwelling season in the Ría de Arousa (Álvarez-Salgado et al. 1996a). Although mixing fluxes decreased considerably during the autumn downwelling (17 to 19 September) and autumn transition (19 to 23 September) compared with July, they contributed to the fertilization of the photic layer despite the dominant downwelling conditions. Vertical advection and mixing induced by the prevailing external forces (shelf winds, continental runoff) conditions the stability of the water column. An elevated stability can make vertical mixing negligible.

The vertical transport of $\mathrm{N}_{\mathrm{T}}$, i.e. $\mathrm{N}_{\mathrm{T}} \cdot V_{\mathrm{Z}}+$ $K_{\mathrm{Z}} \cdot\left(\Delta \mathrm{N}_{\mathrm{T}} / \Delta z\right)$, depended more on the nutrient profile $(60 \pm 20 \%, \mathrm{p}<0.08)$ than on the vertical velocity $(40 \pm$ $20 \%, \mathrm{p}<0.03$ ) with $\mathrm{r}^{2}=0.85, \mathrm{n}=6$ and $\mathrm{p}<0.03$ for the multiple linear correlation of $\mathrm{N}_{\mathrm{T}} \cdot V_{\mathrm{Z}}+K_{\mathrm{Z}} \cdot\left(\Delta \mathrm{N}_{\mathrm{T}} / \Delta z\right)$ with the average $N_{T}$ concentration $\left(\bar{N}_{T}\right)$ and the total (advective + diffusive) vertical velocity $\left(V_{\mathrm{Z}}+K_{\mathrm{Z}} / \Delta z\right)$.

The hydrography (stratification vs. homogenization) and dynamics (upwelling vs. downwelling) condition the relative importance of vertical convection and turbulent mixing in the fertilization of the photic layer. Mixing became the most important fertilization mechanism under strong upwelling conditions and compensated the downward vertical convection during downwelling episodes, ensuring the fertilization of the photic layer. 


\section{A geochemical approach to the origin and fate of biogenic materials}

The Ría de Vigo acts as a transient biogeochemical reactor driven by a succession of upwelling/downwelling episodes separated by short periods of wind calm. Therefore, the metabolic condition of this marine ecosystem can be evaluated with a transient geochemical box model. The transient regime of the ría increases its efficiency as a nutrient trap and allows the accumulation of organic matter recently synthesized within the system. The efficiency as a nutrient trap is calculated from the ratio (o - i)/i. It was higher under weak $(66 \pm 3 \%)$ and strong summer upwelling $(61 \pm$ $3 \%$ ) than under weak autumn upwelling (56 $\pm 3 \%$ ). Similar efficiencies (66\%) were obtained during the upwelling season in the adjacent Ría de Arousa (Álvarez-Salgado et al. 1996b). The trapped nutrients can accumulate or be consumed: $56 \%, 43 \%$ and $73 \%$ of the net entry of nutrients accumulated in the system during strong and weak summer upwelling and weak autumn upwelling, respectively (Table 4). In this situation, net uptake by phytoplankton was delayed due to the low biomass in newly upwelled waters and the lag time for adaptation to the light conditions. Nutrients accumulated during upwelling support the productivity of the ría during the subsequent relaxation, when no entry of new nutrients from the shelf occurs. In the Ría de Arousa, most of the nutrients trapped during the upwelling season are transformed into organic matter (87\%). Hydrodynamic accumulation is more important in the outer ría: up to $40 \%$ (Álvarez-Salgado et al. 1996b).

During downwelling/relaxation events, the ría acts as a nutrient source. During the summer relaxation, there was a net loss of the previously accumulated $\mathrm{N}$-nutrients $(74 \%$ was exported to the shelf and the remaining $26 \%$ was consumed by phytoplankton). During the autumn downwelling, there was also a net $\mathrm{N}$-nutrients loss (87\% exported, $13 \%$ consumed). In contrast, during the autumn relaxation, $28 \%$ of the nutrients regenerated into the system were exported and the remaining $72 \%$ were accumulated (Table 4 ).

Under strong upwelling, phytoplankton in the photic layer is exported to the shelf. It is replaced by the slowgrowing cells in the upwelled subsurface water, not adapted to the light conditions of the photic layer (Zimmerman et al. 1987), and most of the upwelled N-nutrients accumulate in the photic layer rather than being consumed. For this reason, nutrient uptake by phytoplankton and, therefore, chl $a$ and PON accumulation, occurred during the spin-down phase of upwelling events, when nutrients are abundant, horizontal transports are reduced and phytoplankton cells are acclimatized (Zimmerman et al. 1987, Álvarez-Salgado et al. 1996b, Pérez et al. 2000). The sampling frequency (twice a week) showed that DON and PON accumulated during upwelling relaxation, in agreement with the observations of dissolved organic matter (DOM) accumulation during the decline of phytoplankton blooms observed in other marine systems (Kirchman et al. 1994, Normann et al. 1995).

Average $\mathrm{NEP}_{\mathrm{T}}$ calculated with transient box models is suitable to quantify the net trophic balance of a transient ecosystem (Smith \& Hollibaugh 1997, Pérez et al. 2000, Álvarez-Salgado et al. 2001). According to our calculations, $\mathrm{NEP}_{\mathrm{T}}$ was negative during July, showing an autotrophic status at the ecosystem level. In September, only during autumn transition was the system strictly heterotrophic $\left(\mathrm{NEP}_{\mathrm{T}}>0\right)$, whereas the rest of the study period was nearly balanced $\left(\mathrm{NEP}_{\mathrm{T}} \sim 0\right)$. The geochemical budget for July 2002 showed a net autotrophic metabolism similar to results of ÁlvarezSalgado et al. (2001) during summer 1997. The differences between the 2 periods derive from the relevance of accumulation versus export of organic matter during July 2002, whereas in July 1997 there was a close coupling between hydrodynamics and biogeochemistry resulting in a near-zero accumulation term. Autumn 1997 (Álvarez-Salgado et al. 2001) was comparable with September 2002. In both periods, the $\mathrm{NEP}_{\mathrm{T}}$ depended mostly on the nutrient stock previously accumulated in the ría.

The periods 15 to 26 July and 17 to 26 September can be considered representative for the typical upwelling-relaxation and downwelling-relaxation events off NW Spain, respectively. Average NEP during July was $107 \mathrm{mg} \mathrm{N} \mathrm{m}^{-2} \mathrm{~d}^{-1}\left(=-\mathrm{NEP}_{\mathrm{T}}\right)$, very close to the estimation of Gilcoto et al. (2001) for the same area (140 mg $\mathrm{N} \mathrm{m}^{-2} \mathrm{~d}^{-1}$, assuming $\mathrm{C} / \mathrm{N}=6.7$ ) during an upwelling relaxation in September 1990. About $25 \%$ of this material was exported to the shelf. In September, only the weak autumn upwelling period was productive $\left(\overline{\mathrm{NEP}}_{\mathrm{T}}=\right.$ $-26 \mathrm{mg} \mathrm{N} \mathrm{m}^{-2} \mathrm{~d}^{-1}$ ), and the fraction exported to the shelf was about $40 \%$. These results are consistent with those of Gago et al. (2003), who estimated that $32 \%$ of the organic carbon was exported to the shelf. The estimations are also comparable with the values given by Waldron et al. (1998) for the Benguela upwelling system, where $34 \%$ of the new production was exported offshore. In the Ría de Arousa, $80 \%$ of NEP was exported to the shelf during the upwelling season of 1989 (Rosón et al. 1999), and $50 \%$ when only the middle ría is considered (Álvarez-Salgado et al. 1996a). Regarding the POM:DOM ratio of NEP, the estimations of Gago et al. (2003) and our own results yield a PON:DON ratio of 60:40. By contrast, the massive culture of mussels on hanging ropes in the Ría de Arousa causes an inverse PON:DON ratio of 30:70 (Álvarez-Salgado et al. 1996a). The results of our study indicate that the PON:DON 
ratio of the exported material was independent of the upwelling intensity. However, Gago et al. (2003) found that this ratio varied within the upwelling intensity during July 1997 in the Ría de Vigo. During the weak autumn upwelling, only PON was exported to the shelf. In contrast, DON was imported from the shelf and accumulated into the system.

The NEP of DON $\left(\mathrm{NEP}_{\mathrm{D}}\right)$ is coupled with the balance of outputs minus inputs of DON (o - i $)_{D}$ only under weak summer upwelling. The ría acts as a DON source during moderate upwelling, as reported by Gago et al. (2003). The importance of the accumulation term during the rest of July and September leads to a decoupling of the production and export of DON and PON. Our results show that most of the material exported to the shelf comes from losses of the material previously accumulated rather than recently produced.

The need to assess the relative importance of the production and accumulation of organic matter in a transient marine ecosystem makes the geochemical approach presented in this paper the most suitable to characterize the metabolic status of the Ría de Vigo at the ecosystem level. Although several previous studies estimated the NP of the Ría de Vigo from mass balances (Tilstone et al. 2000, Gilcoto et al. 2001, Gago et al. 2003, Álvarez-Salgado \& Gilcoto 2004), none of them either used current meter records or considered the lateral variability of the currents and the chemical species concentrations. In addition, the mass balances were obtained simultaneously with oxygen production/respiration, microzooplankton grazing and sedimentation rates in the present study (see Piedracoba et al. 2008, this volume), which allowed, for the first time, a direct comparison of the in situ and in vitro approaches for the estimation of NP.

Acknowledgements. We thank the members of the Department of Oceanography of the Instituto de Investigacións Mariñas (CSIC) and the Group of Physical Oceanography of the University of Vigo who participated in this programme. This work would not have been possible without the cooperation of the captain, crew and technicians of RV 'Mytilus'. We are also grateful to E. A. Fanjul and B. Morón (Puertos del Estado) for the meteorological data from the Silleiro buoy. Financial support for this work came from the Spanish Ministerio de Educación y Ciencia (MEC), grant nos. REN2000-0880-C02-01 and -02 and the Xunta de Galicia grant no. PGIDT01MAR40201PN. This is contribution no. 39 of the Unidad Asociada GOFUVICSIC. S.P. and M.N.-C. received predoctoral fellowships from the MEC and postgraduate fellowships from the CSIC-I3P programme and M.G. received funding from the postdoctoral programme 'Parga Pondal' of the 'Xunta de Galicia'.

\section{LITERATURE CITED}

Álvarez-Salgado XA, Gilcoto M (2004) Inferring nitrification rates with an inverse method in a coastal upwelling system, Ría de Vigo (NW Spain). Mar Ecol Prog Ser 276:3-17
Álvarez-Salgado XA, Rosón G, Pérez FF, Pazos Y (1993) Hydrographic variability off the Rías Baixas (NW Spain) during the upwelling season. J Geophys Res 98:14447-14455

Álvarez-Salgado XA, Rosón G, Pérez FF, Figueiras FG, Pazos $Y$ (1996a) Nitrogen cycling in an estuarine upwelling system, the Ría de Arousa (NW Spain). I. Short-time-scale patterns of hydrodynamic and biogeochemical circulation. Mar Ecol Prog Ser 135:259-273

Álvarez-Salgado XA, Rosón G, Pérez FF, Figueiras FG, Ríos AF (1996b) Nitrogen cycling in an estuarine upwelling system, the Ría de Arousa (NW Spain). II. Spatial differences in the short-time-scale evolution of fluxes and net budgets. Mar Ecol Prog Ser 135:275-288

Álvarez-Salgado XA, Gago J, Míguez BM, Gilcoto M, Pérez FF (2000) Surface waters of the NW Iberian margin: upwelling on the shelf versus outwelling of upwelled waters from the Rías Baixas. Estuar Coast Shelf Sci 51:821-837

Álvarez-Salgado XA, Gago J, Míguez BM, Pérez FF (2001) Net ecosystem production of dissolved organic carbon in a coastal upwelling system: the Ría de Vigo, Iberian margin of the North Atlantic. Limnol Oceanogr 46:135-147

Blanton JO, Tenore KR, Castillejo F, Atkinson LP, Schwing FB, Lavin A (1987) The relationship of upwelling to mussel production in the rias on the western coast of Spain. J Mar Res 45:497-511

Buesseler KO (1991) Do upper-ocean sediment traps provide an accurate record of particle flux? Nature 353:420-423

Carter HH, Najarian TO, Pritchard DW, Wilson RE (1979) The dynamics of motion in estuaries and other coastal water bodies. Rev Geophys 17:1585-1590

Castro CG, Álvarez-Salgado XA, Figueiras FG, Pérez FF, Fraga $F$ (1997) Transient hydrographic and chemical conditions affecting microplankton populations in the coastal transition zone of the Iberian upwelling system (NW Spain) in September 1986. J Mar Res 55:321-352

Cotner JB, Biddanda BA (2002) Small players, large role: microbial influence on biogeochemical processes in pelagic aquatic ecosystems. Ecosystems 5:105-121

del Giorgio PA, Duarte CM (2002) Respiration in the open ocean. Nature 420:379-384

Diz P, Francés G, Costas S, Souto C, Alejo I (2004) Distribution of benthic foraminifera in coarse sediments, Ría de Vigo, NW Iberian Margin. J Foraminif Res 34:258-275

Ducklow HW, Carlson CA, Bates NR, Knap AH and 5 others (1995) Dissolved organic carbon as a component of the biological pump in the North Atlantic Ocean. Philos Trans R Soc Lond B 348:161-167

Dugdale RC, Goering JJ (1967) Uptake of new and regenerated forms of nitrogen in primary production. Limnol Oceanogr 12:196-206

Eppley RW, Peterson BJ (1979) Particulate organic matter flux and planktonic new production in the deep ocean. Nature 282:677-680

Fraga F (1981) Upwelling off the Galician coast, northwest Spain. In: Richards FA (ed) Coastal upwelling. American Geophysical Union, Washington, DC, p 176-182

Gago J, Alvarez-Salgado XA, Gilcoto M, Pérez FF (2003) Assessing the contrasting fate of dissolved and suspended organic carbon in a coastal upwelling system ('Ría de Vigo', NW Iberian Peninsula). Estuar Coast Shelf Sci 56: 271-279

Gilcoto M, Álvarez-Salgado XA, Pérez FF (2001) Computing optimum estuarine residual fluxes with (OERFIM) a multiparameter inverse method: application to the Ría de Vigo (NW Spain). J Geophys Res 106:31303-31318

Gilcoto M, Pardo PC, Álvarez-Salgado XA, Pérez FF (2006) Exchange fluxes between the Ría de Vigo and the shelf: a 
bidirectional flow forced by remote wind. J Geophys Res 112, doi 10.1029/2005JC003140

Hansell DA, Ducklow HW, Macdonald AM, Baringer MON (2004) Metabolic poise in the North Atlantic Ocean diagnosed from organic matter transports. Limnol Oceanogr 49: 1084-1094

Herrera JL, Piedracoba S, Varela RA, Rosón G (2005) Spatial analysis of the wind field on the western coast of Galicia from accurate measurements. Cont Shelf Res 25:1728-1748

Janzen CD, Wong KC (2002) Wind forced dynamics at the estuary-shelf interface of a large coastal plain estuary. J Geophys Res 107:3138

Kirchman DL, Ducklow HW, McCarthy JJ, Garside C (1994) Biomass and nitrogen uptake by heterotrophic bacteria during the spring phytoplankton bloom in the North Atlantic Ocean. Deep-Sea Res 41:879-895

Legendre L, Gosselin M (1989) New production and export of organic matter to the deep ocean: consequences of some recent discoveries. Limnol Oceanogr 34:1374-1380

Legendre L, Rassoulzadegan F (1995) Plankton and nutrient dynamics in marine waters. Ophelia 41:153-172

Longhurst AR (1991) Role of the marine biosphere in the global carbon cycle. Limnol Oceanogr 36:1507-1526

Míguez BM, Fariña-Busto L, Figueiras FG, Perez FF (2001) Succession of phytoplankton assemblages in relation to estuarine hydrodynamics in the Ría de Vigo: a box model approach. Sci Mar 65(Suppl 1):65-76

Munk WH, Anderson ER (1948) Notes on the theory of the thermocline. J Mar Res:3:276-295

Nogueira E, Pérez FF, Ríos AF (1997) Seasonal patterns and long-term trends in an estuarine upwelling ecosystem (Ría de Vigo, NW Spain). Estuar Coast Shelf Sci 44:285-300

Normann B, Zweifel UL, Hopkinson CS Jr, Fry B (1995) Production and utilization of dissolved organic carbon during an experimental diatom bloom. Limnol Oceanogr 40: 898-907

Pardo PC, Gilcoto M, Pérez FF (2001) Short-time scale coupling between themohaline and meteorological forcing in the Ría de Pontevedra. Sci Mar 65(Suppl 1):229-240

Pérez FF, Álvarez-Salgado XA, Rosón G (2000) Stoichiometry of the net ecosystem metabolism in a coastal inlet affected by upwelling. The Ría de Arousa (NW Spain). Mar Chem 69:217-236

Piedracoba S, Álvarez-Salgado XA, Rosón G, Herrera JL (2005) Short-timescale thermohaline variability and residual circulation in the central segment of the coastal upwelling system of the Ría de Vigo (northwest Spain) during four contrasting periods. J Geophys Res 110, doi: 10.1029/2004JC002556

Piedracoba S, Nieto-Cid M, Teixeira IG, Garrido JL, ÁlvarezSalgado XA, Rosón G, Castro CG, Pérez FF (2008) Physical-biological coupling in the coastal upwelling system of the Ría de Vigo (NW Spain). II: In vitro approach. Mar Ecol Prog Ser 353:41-53

Quiñones RA, Platt T (1991) The relationship between the $\mathrm{f}$-ratio and the $\mathrm{P}: \mathrm{R}$ ratio in the pelagic ecosystem. Limnol Oceanogr 36:211-213

Editorial responsibility: Otto Kinne (Editor-in-Chief), Oldendorf/Luhe, Germany
Prego R, Fraga F (1992) A simple model to calculate the residual flows in a Spanish Ria. Hydrographic consequences in the Ria of Vigo. Estuar Coast Shelf Sci 34:603-615

Rosón G, Álvarez-Salgado XA, Pérez FF (1997) A non-stationary box model to determine residual fluxes in a partially mixed estuary, based on both thermohaline properties. Application to the Ría de Arousa (NW Spain). Estuar Coast Shelf Sci 44:249-262

Rosón G, Álvarez-Salgado XA, Pérez FF (1999) Carbon cycling in a large coastal embayment, affected by winddriven upwelling: short-time-scale variability and spatial differences. Mar Ecol Prog Ser 176:215-230

Serret P, Robinson C, Fernández E, Teira E, Tilstone G (2001) Latitudinal variation of the balance between plankton photosynthesis and respiration in the E Atlantic Ocean. Limnol Oceanogr 46:1642-1652

Smith SV, Hollibaugh JT (1993) Coastal metabolism and oceanic organic carbon balance. Rev Geophys 31:75-89

Smith SV, Hollibaugh JT (1997) Annual cycle and interannual variability of ecosystem metabolism in a temperate climate embayment. Ecol Monogr 67:509-533

Souto C, Gilcoto M, Fariña-Busto L, Pérez FF (2003) Modeling the residual circulation of a coastal embayment affected by wind-driven upwelling: circulation of the Ría de Vigo (NW Spain). J Geophys Res 108:3340

Strickland JD, Parsons TR (1972) A practical handbook of seawater analysis, 2nd edn. Bull Fish Res Board Can, 167

Tilstone GH, Míguez BM, Figueiras FG, Fermín EG (2000) Diatom dynamics in a coastal ecosystem affected by upwelling: coupling between species succession, circulation and biogeochemical processes. Mar Ecol Prog Ser 205:23-41

UNESCO (1985) The international system of units (SI) in oceanography. UNESCO Tech Pap Mar Sci 45:1-124

Wafar MVM, Le Corre P, L'Helguen S (1995) f-Ratios calculated with and without urea uptake in nitrogen uptake by phytoplankton. Deep-Sea Res I 42:1669-1674

Waldron HN, Probyn TA, Brundrit GB (1998) Carbon pathways and export associated with the southern Benguela upwelling system: a re-appraisal. S Afr J Mar Sci 19: 113-118

Williams PJ le B (1998) The balance of plankton respiration and photosynthesis in the open oceans. Nature 394:55-57

Wollast R (1993) Interactions of carbon and nitrogen cycles in the coastal zone. In: Wollast R, Mackenzie FT, Chou L (eds) Interactions of C, N, P and S biogeochemical cycles and global change, NATO ASI Series, Vol 14. Springer, Berlin, p 195-210

Wong KC, Moses-Hall JE (1998) The tidal and subtidal variations in the transverse salinity and current distributions across a coastal plain estuary. J Mar Res 56:489-517

Wooster WS, Bakun A, McClain DR (1976) The seasonal upwelling cycle along the eastern boundary of the North Atlantic. J Mar Res 34:131-141

Zimmerman RC, Kremer JN, Dugdale RC (1987) Acceleration of nutrient uptake by phytoplankton in a coastal upwelling ecosystem: a modelling analysis. Limnol Oceanogr 40: 299-305

Submitted: October 10, 2006; Accepted: July 30, 2007

Proofs received from author(s): December 21, 2007 